\title{
Geometric Modeling in Some Micromorphological Structures
}

\author{
Ali Özdemir ${ }^{1}$ ve Canan Özdemir ${ }^{2 *}$ \\ ${ }^{1}$ Manisa Celal Bayar University, Faculty of Arts and Sciences,Department of Mathematics, Manisa, Turkey, (ORCID: 0000-0001-9330-7084), acaozdemir@gmail.com \\ 2* Manisa Celal Bayar University, Faculty of Arts and Sciences, Department of Biology, Manisa, Turkey, (ORCID: 0000-0003-1316-4146), cozdemir13@gmail.com
}

(1st International Conference on Applied Engineering and Natural Sciences ICAENS 2021, November 1-3, 2021)

(DOI: 10.31590 /ejosat.996946)

ATIF/REFERENCE: Özdemir, A. \& Özdemir, C. (2021). Geometric Modeling in Some Micromorphological Structures. Avrupa Bilim ve Teknoloji Dergisi, (28), 270-274.

\begin{abstract}
In this study, we determined that some micromorphological structures of plants have geometric models and mathematical formulas. There are specialized structures in plants that perform tasks such as making usable, storing and transmitting the products formed as a result of metabolic activities. These structures take different shapes depending on the complexity of their functions. These shapes enable them to perform their duties in the most efficient way. As a result of the examinations under the microscope, it was observed that plant crystals and vascular tissue elements from these structures have special geometric shapes that provide them with important advantages such as small space and durability. In the microscopic observations of the plants we examined, it was determined that the crystals and some transmission tissue elements that serve to transmit water and dissolved minerals in plants show a minimal surface feature, which has an important place in geometry. Minimal surfaces are defined as surfaces with zero mean curvature and expressed with mathematical formulas. In addition, it has been determined that these structures show geometric patterns called helicoid and elongated triangular bipyramid. The schematic shapes of these geometric models and the photographs taken from the plant samples under the microscope as a result of laboratory studies are given in the study.
\end{abstract}

Keywords: Geometric modelling, Micromorphology, Minimal surface.

\section{Bazı Mikromorfolojik Yapılarda Geometrik Modellemeler}

\section{$\ddot{0} \mathbf{z}$}

Bu çalışmada, bitkilerin bazı mikromorfolojik yapılarının geometrik modellere ve matematiksel formüllere sahip olduğunu belirledik. Bitkilerde metobolik faaliyetler sonucu meydana gelen ürünlerin kullanılabilir hale gelmesi, depolanması, iletilmesi gibi görevleri yapan özelleşmiş yapılar bulunmaktadır. Bu yapılar görevlerinin kompleksliğine bağlı olarak farklı şekiller alırlar. Bu şekiller onların görevlerini en verimli şekilde yapabilmelerini sağlar yapıdadır. Mikroskop altında incelemeler sonucunda bu yapılardan bitki kristalleri ve iletim doku elemanlarının onlara az yer kaplama ve dayanıklılık gibi önemli avantajlar sağlayan özel geometrik şekillere sahip oldukları gözlendi. İncelediğimiz bitkilerin mikroskobik gözlemlerinde, kristallerin ve bitkilerde su ve çözünmüş minerallerin iletilmesine hizmet eden bazı iletim doku elemanlarının geometride önemli bir yere sahip olan minimal bir yüzey özelliği gösterdikleri tespit edildi. Minimal yüzeyler sıfir ortalama eğriliği olan yüzeyler olarak tanımlanıp matematiksel formüller ile ifade edilir. Ayrıca bu yapıların helikoid ve uzatılmış üçgen bipiramit (Elongated triangular bipyramid) olarak adlandırılan geometrik modeller gösterdikleri tepit edilmiştir. Bu geometrik modellere ait şematik şekiller ve labaratuvar çalışmaları sonucu bitki örneklerinden mikroskopta çekilmiş fotoğrafları çalışmada verilmiştir.

Keywords: Geometric modelling, Micromorphology, Minimal surface 


\section{Introduction}

There are specialized structures in plants that perform tasks such as making usable, storing and transmitting the products formed as a result of metabolic activities. These structures take on specialized shapes depending on the complexity of their functions. These shapes enable them to perform their duties in the most efficient way.

Plant crystals, one of these structures, are the places where mineral acid salts formed as a result of metabolism in many plants are stored in a way that takes up the least space. Some of these stored inorganic salts are harmful to the plant. The harmful ones combine with the calcium of the plant and turn into these crystals and become harmless to the plant cells. Plant crystals display an astonishing variety of shapes. The most common are raphide crystals, which are in the form of regular rods [1]. The shaping of plant crystals is not a simple structure; they are formed in certain shapes and sizes by this biomineralization process [2], [3].

Another structure that has specialized shapes in plants is the elements of xylem, which is one of the tissues that serve as a transmission in plants. These structures also consist of highly specialized cells. Some of these tissue cells die at maturity, but the woody cell walls remain and take different shapes and form pipe like structures. These structures serve to convey water and dissolved minerals in plants to the places where they are needed [4], [5], [6]. They perform these services in the most efficient way thanks to their geometric shapes.

In this study, it has been shown that the micromorphological structures of some plant parts have geometric properties and can be described mathematically. There are some mathematical studies about the visible external structures of plants in the literature [7], [8]. However, mathematical studies on the micromorphological structures of the plants that constitute the subject of our study are quite limited [9], [10].

\section{Material and Method}

For tracheal elements, leaf and stem parts where conductive tissues can be easily observed were evaluated. Anatomical sections were taken using fresh samples of these parts and samples fixed in $70 \%$ ethanol. Anatomical sections were colored using safranin and fast-green dyes [11]. The obtained samples were examined using a Leica DM 3000 light microscope. Afterwards, photographs of micromorphological structures were taken using a motorized Leica DM 3000 microscope. In mathematical evaluations, literature information about the definitions and mathematical formulas of geometric structures was evaluated [12],[13], [14], [15], [16], [17]. In addition, the structures of the geometric models obtained from these definitions were shown with figures (Figure 1-5).

\section{Conclusion and Discussion}

In our study, we observed that the microscopic structures of raphide crystals, which we observed in the sections we took e-ISSN: 2148-2683 from the leaves of the plant samples, did not have an ordinary shape, but showed prismatic features. It was determined that the prismatic structures of some of them had structures defined as "elongated triangular bipyramid" in geometry (Figure 1,2). The elongated triangular bipyramid is one of the Johnson solids $\left(\mathrm{J}_{14}\right)$, one of the important definitions in geometry. In geometry, a Johnson solid is a convex polyhedron with a regular polygon on each side. It is not necessary for every face to be the same polygon or for the same polygons to converge around every vertex. The Johnson solid is one of 92 convex polyhedra. These polyhedra were named by Norman Johnson, who first listed them in 1966 [18]. This study determined that the microscopic structures of raphid crystals have Johnson solid geometric structure. The Johnson solid symmetry group is dihedral. In mathematics, a dihedral group is a set of symmetries of a regular polygon, including rotations and reflections.
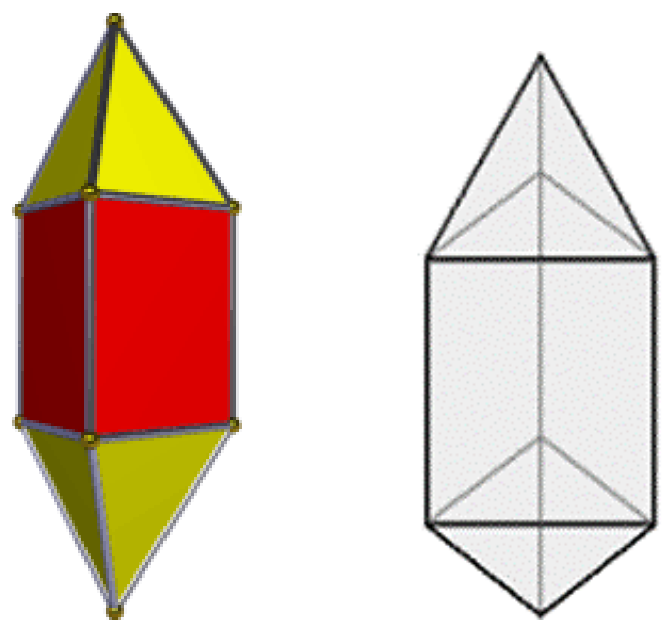

Fig. 1 Geometric model diagram of Elongated triangular bipyramid [18].
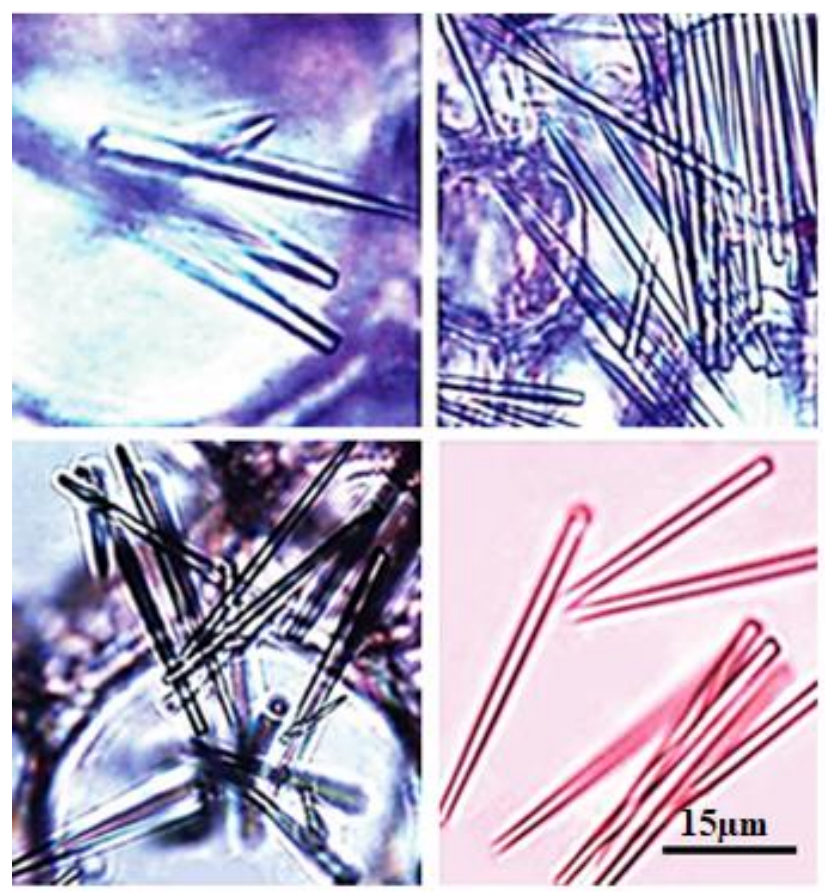

Fig. 2 Light microscope images of raphide crystals in the examined plant (Scilla luciliae, S. forbesii, S.sardensis) parts. 
For the symmetry group of a regular polygon; Provided that all surfaces are regular and have side length a, the following formulas can be used by taking the volume (V), surface area (A) and height $(\mathrm{H})$ :

$V=\left(\frac{1}{12}(2 \sqrt{2}+3 \sqrt{3})\right) \cdot a^{3} \approx 0.668715 \ldots a^{3}$

$H=\frac{3+2 \sqrt{6}}{3} \cdot a \approx 2.63299 \ldots a$

$A=\left(\frac{3}{2}(2+\sqrt{3})\right) \cdot a^{2} \approx 5.59808 \ldots a^{2}$

At the same time, it has been observed that these prismatic crystals exhibit a minimal surface feature, which has an important place in geometry. Minimal surface; is the surface with the 'smallest area' on which we can fill a defined space given to us. Mathematically, the minimum surface can also be characterized as the surface of the minimum surface area for the given boundary conditions. On a minimal surface, the curvature along the major planes of curvature is equal and opposite at each point. This makes the mean curvature zero (Figure 3).

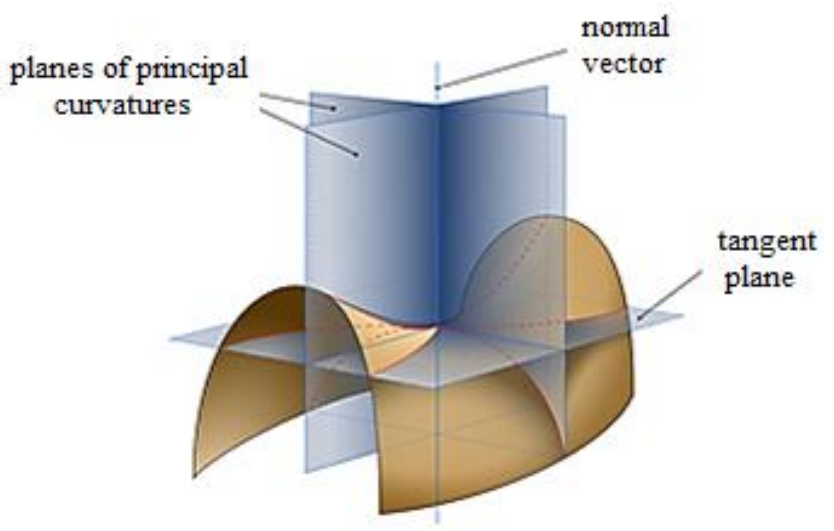

Fig. 3 The diagram of minimal surface.

A minimal surface can be represented by the triad of the analytic function as:

$$
\emptyset_{1}^{2}+\emptyset_{2}^{2}+\emptyset_{13}^{2}+0
$$

Then the actual parameterization

It is obtained as.

$$
x_{k}=R \int \emptyset_{k}(\zeta) d(\zeta)
$$

On the other hand, for an analytic function

$f$ and $a$ meromorphic function $g$, triple of functions

$$
\emptyset_{1}(\zeta)=f(1-\mathrm{g} 2)
$$

$\emptyset_{2}(\zeta)=i f(1+\mathrm{g} 2)$

$$
\emptyset_{3}(\zeta)=2 f g
$$

$f$, is analytical as long as it has $\geq \mathrm{m}$ of order zero at each pole of $g$ of order $m$. This result gives us a minimal surface in terms of Enneper-Weierstrass parameters.

Meusnier found that a plane is an insignificant minimal surface, and the first examples of minimal surfaces were catenoid and helicoid geometric structures in 1776 [19].

We observed that some vascular tissue elements have a spiral structure in the plant samples that we examined the vascular tissues. We also observed that these elements are structures whose definitions can be found in geometry. We have determined that they structure that can be definied is "the helicoid minimal surface" in geometry (Figures 4, 5).

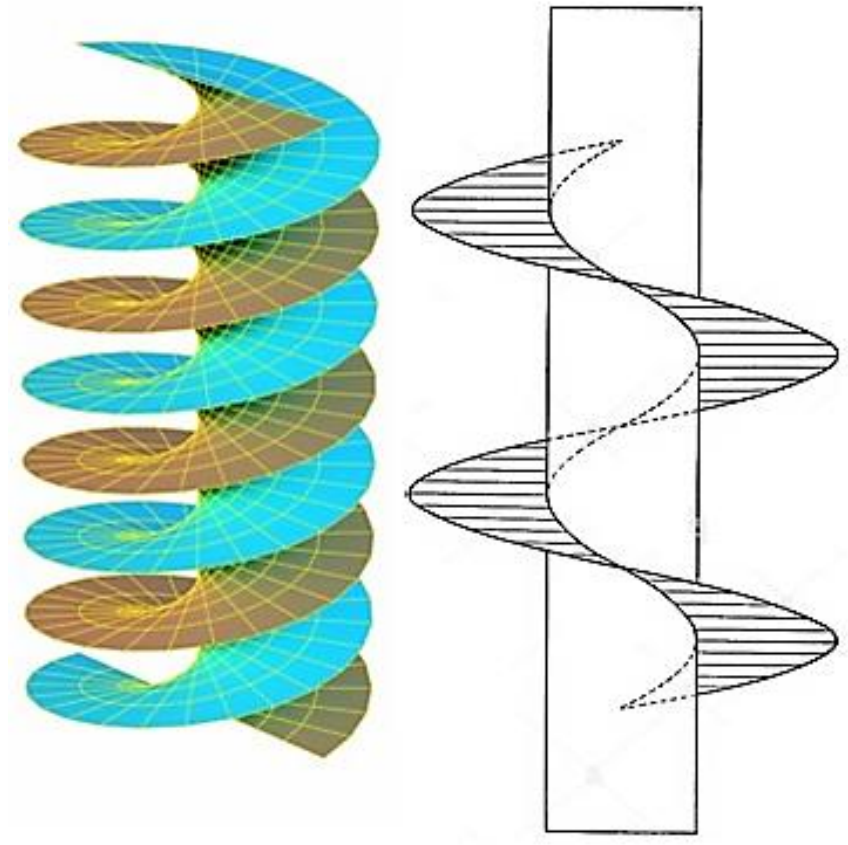

Fig. 4. Geometric structure diagram of the helicoid model. (Http://www.indiana.edu/minimal/archive/Classical/Classical /Helicoid/web/index.htm)

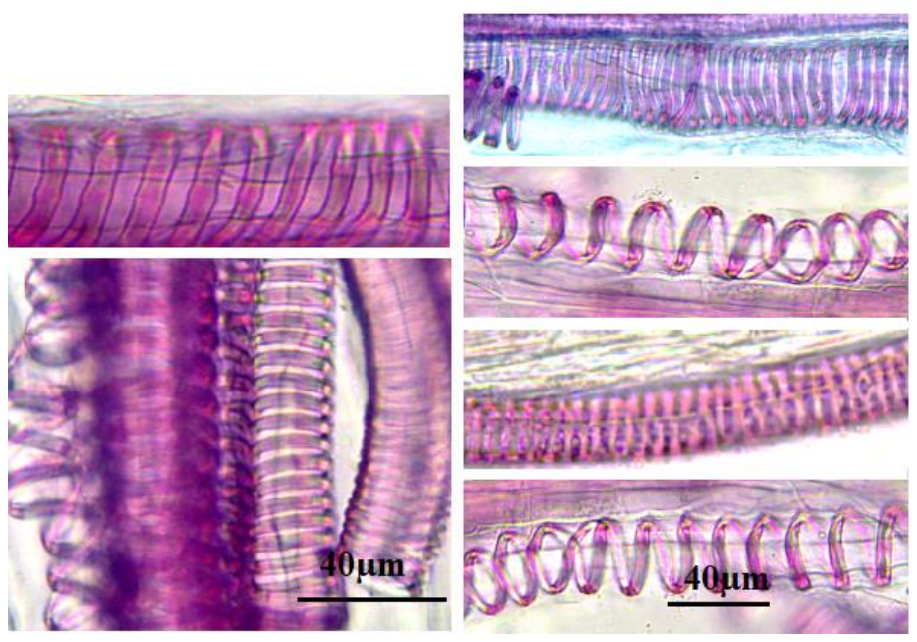

Fig. 5 Helicoid structures of vascular tissue elements in plant parts examined under the light microscope. 
The helicoid is the third known minimal surface after the plane and the catenoid. It was described by Euler in 1774 and by Jean Baptiste Meusnier in 1776 [19]. It gets its name from the similarity of the helix: for every point on the helix, there is a helix passing through that point inside the helix. Helicoid is also a striated surface (and a right conoid), meaning it is a trace of a line. Alternatively, for any point on the surface there is a line running through the surface.

Helicoid and catenoid are parts of a helix-catenoid minimal surface family. A spiral is also a translational surface in the differential geometry sense. It is shaped like a helicoid Archimedean screw, but extends infinitely in all directions. The helicoid can be defined in cartesian coordinates with the following parametric equations (Figure 4).

$$
\begin{aligned}
& x=\rho \cos (\alpha \theta), \\
& \mathrm{y}=\rho \sin (\alpha \theta), \\
& \mathrm{z}=\theta,
\end{aligned}
$$

Here $\rho$ and $\theta$ vary from minus infinity to plus infinity, while $\alpha$ is a constant. If $\alpha$ is positive, the helicoid is right-handed; if it is negative, it is left-sided [19].

As a result of this study, it has been seen that some of the micromorphological shape definitions of the plants we examined have the features that are found in geometry and are defined by parametric equations. It was determined in the study that plant crystals and vascular tissue elements can be defined as geometric minimal surfaces, and they also have elongated triangular bipyramid and helicoid geometric metalls. The minimal surface is the "smallest area" surface on which we can fill a defined space. Minimal surfaces are powerful formations that not only reduce their space but also maintain their physical durability.

The first geometric studies on the microscopic structures of plants were made with regularly arranged epidermis cells. In the study, numerical evaluation of the sequences of these cells was made [20].

Researchers, who made microscopic studies with the roots of some geophyte taxa, found results similar to the results of our study with stems and leaves. Researchers have observed raphid crystals with geometric patterns in their studies [8]. In another study, researchers observed druse crystals, unlike our study, in their microscopic studies on the stems of different taxa.

They found that these crystals have a minimal surface, similar to our study. However, while we observed in our study that raphide crystals have an elongated triangular bipyramid geometric pattern, the researchers found that druse crystals have a great stellated dodecahedron geometric shape [21].

In the microscopic structures of the leaves and stems of the plant specimens we examined in our study, raphide-shaped plant crystals were detected, being more concentrated in the leaf.

It has been observed that the shapes of these crystals are not ordinary, they correspond to special definitions in geometry and are expressed by formulas.
On the other, it has been observed that the shapes of some xylem elements, which consist of a spiral structure, have geometric patterns in the stem and leaf anatomy of the same plant specimens. Similar results were obtained in some studies on different plant samples and plant parts. [8], [9].

Considering the complexity of the tasks of these plant parts with these unusual special geometric shapes, it becomes clear how important the contributions of their geometric structures are.

With this study, it was provided to examine the micromorphological structures of plants from a different perspective. In the literature, there are studies defined with the help of geometric models and mathematical formulas. However, these studies are mostly on visible structures. In our studies, we tried to describe microscopic structures with geometric models. We think that our study will bring a different perspective for future researchers.

\section{References}

1. Franceschi V.r., H.T., Horner. Calcium oxalate crystals in plants. Botany Review, 1980. 46: 361-427. Vincent R.F., P. Aul. Calcium oxalate in plants: formation and function. Annual Review of Plant Biology, 2005. 56: 41-71.

2. Bouro P.N., S. Weiner, 1. Addadi. Calcium oxalate crystals in tomato and tobacco plants: Morphology and in vitro interactions of crystal associated macromolecules. Chemistry European Journal, 2001. 7(9): 1881-1888.

3. Fukuda, H. Tracheary Element for- mation as a Model System of Cell Differentia- tion. Inter. Rev. Cytol. 1992. 136, 289-332.

4. Hofte, H. (2010) Plant Cell Biology: How to Pattern a Wall. Curr. Biol. 20(10), 450-2.

5. Devillard, C.and Walter, C. (2014) Formation of Plant Tracheary Elements in Vitro - A Review. NZ. J. For Sci. 44, 1-14.

6. Oppenheimer, P.E. Real Time Design and Animation of Fractal Plants and Trees. Sig- graph, 20, 55-64. https://doi.org/10.1145/ 15886.15892. 1986.

7. Kaitaniemia, J., S. Hananb, and P.M. Room. Virtual Sorghum: Visualisation of Partitioing and Morphogenesis. Computers and Electronics in Agriculture. 2000. 28, 195-205.

8. Ozdemir, A. Geometric Model of Microscopic Raphide Crystals In Plant. Botanica. 2021. 27, (1): 62-68.

9. Ozdemir, A. Definiation of annular Type Tracheal Elements of Chard and Numerical Comparision. Journal of Agricultural Faculty of Gaziosmanpaşa University. 2018. 35, (3): 227-230.

10. Bozdag, B., O. Kocabas, Y. Akyol, and C.Ozdemir. New Staining Method For Hand-Cut In Plant Anatomy Studies. Marmara Pharm J. 2016 .20,184-190.

11. William, H.M. and P.Joaquin. The classical Theory of Minimal Surfaces. Bull. Amer. Math. Soc. 2011. 48(3), 325-407.

12. Gray, A. Minimal Surfaces" and "Mini- mal Surfaces and Complex Variables." Ch. 30 and 31 in Modern Differential Geometry of Curves and Surfaces with Mathematica, 2nd ed.Boca Raton, FL: CRC Press, 681734. 1997. 
13. Lagrange, J.L. Trial of a new method to determine the maxima and minima of indefinite integral formulas. Miscellanea Taurinensia 2, 1760. 325(1), 173-199. (in French).

14. Weisstein, E.W. Catenoid. From Math- World-A Wolfram Web Resource. https://math- world. wolfram. com/Catenoid.html. 2017.

15. Fomenko, A.T. and A.A. TuzhilinEle- ments of the Geometry and Topology of Mini- mal Surfaces in Threedimensional Space. AMS Bookstore Press, ISBN 978-08218-4552-3. 1991.

16. Hoffman, D. and H.M. William. The Global Theory of Properly Embedded Minimal Surfaces. Pacific J. of Math. 1987. 128,361-366.

17. Johnson N.W. Convex solids with regular faces. Canadian Journal of Mathematics, 1966. 18: 169-200.

18. Meusnier, J.B. Memory on the curvature of surfaces. Mem. of foreign scholars. 1776. 10, 477-510. (in French).

19. Hoffman D.: The computer-aided discovery of new embedded minimal surfaces. Mathematical Intelligencer. 19879. 8-21.

20. Robert Br., W. Korn, R. M. Spaldıng, The Geometry of Plant Epidermal Cells. New Phytol. 1973. 72, 13571365.

21. Ozdemir, A. C. Özdemir. Geometric definitıon of druse crystal in plant cells. J. Indian bot. 2021. 101 (1\&2) 146151. 